\title{
Risk factors for atopic and non-atopic asthma in a rural area of Ecuador
}

\author{
Ana Lucia Moncayo, ${ }^{1}$ Maritza Vaca, ${ }^{2}$ Gisela Oviedo, ${ }^{2}$ Silvia Erazo, ${ }^{2}$ Isabel Quinzo, ${ }^{2}$ \\ Rosemeire L Fiaccone, ${ }^{3}$ Martha E Chico, ${ }^{2}$ Mauricio L Barreto, ${ }^{1}$ Philip J Cooper ${ }^{4}$
}

- Supplementary tables are published online only. To view these files please visit the journal online http://thorax.bmj. com/content/vol65/issue5

${ }^{1}$ Instituto de Saúde Coletiva, Universidade Federal da Bahia, Salvador, Bahia, Brazil

${ }^{2}$ Instituto de Microbiologia, Universidad San Francisco de Quito, Quito, Ecuador ${ }^{3}$ Instituto de Matemática, Universidade Federal da Bahia, Salvador, Bahia, Brazil ${ }^{4}$ Centre for Infection, St George's University of London, Tooting, London, UK

\section{Correspondence to}

Miss Ana Lucia Moncayo, Instituto de Saúde

Coletiva-Universidade Federal da Bahia, Rua Basílio da Gama, s/n, Salvador, Bahia, CEP: 40.110-040 Brazil; almoncayo@hotmail.com

Received 2 September 2009 Accepted 17 January 2010

\section{ABSTRACT}

Background Asthma has emerged as an important public health problem of urban populations in Latin America. Epidemiological data suggest that a minority of asthma cases in Latin America may be associated with allergic sensitisation and that other mechanisms causing asthma have been overlooked. The aim of the present study was to investigate risk factors for atopic and non-atopic asthma in school-age children.

Methods A cross-sectional study was conducted among 3960 children aged 6-16 years living in AfroEcuadorian rural communities in Esmeraldas province in Ecuador. Allergic diseases and risk factors were assessed by questionnaire and allergic sensitisation by allergen skin prick reactivity.

Results A total of 390 (10.5\%) children had wheeze within the previous 12 months, of whom $14.4 \%$ had at least one positive skin test. The population-attributable fraction for recent wheeze associated with atopy was 2.4\%. Heavy Trichuris trichiura infections were strongly inversely associated with atopic wheeze. Non-atopic wheeze was positively associated with maternal allergic symptoms and sedentarism (watching television ( $>3 \mathrm{~h} /$ day)) but inversely associated with age and birth order.

Conclusions The present study showed a predominance of non-atopic compared with atopic wheeze among schoolchildren living in a poor rural region of tropical Latin America. Distinct risk factors were associated with the two wheeze phenotypes and may indicate different causal mechanisms. Future preventive strategies in such populations may need to be targeted at the causes of non-atopic wheeze.

\section{INTRODUCTION}

An estimated 300 million people have asthma worldwide, and the prevalence has increased over recent decades among children living in industrialised countries, ${ }^{1}$ and may also be increasing in developing countries where such increases may be linked to environmental changes associated with urbanisation and the acquisition of a 'modern' lifestyle. ${ }^{12}$ The multicentre ISAAC (International Study of Asthma and Allergies in Childhood) phase III study estimated an annual increase in prevalence of current wheeze of $0.32 \%$ among adolescents aged 13-14 years between the 15 study centres in nine Latin American countries. ${ }^{3}$

Atopy is a consistent risk factor for asthma from many epidemiological studies. The proportion of asthma attributable to atopy in children has been estimated to be $38 \%$, but there is considerable variation between studies $(25-63 \%) .{ }^{4}$ The ISAAC phase II study showed that the population fraction of asthma attributable to atopy differed greatly between countries according to economic development, being $40.7 \%$ in study centres from 'affluent' countries and $20.3 \%$ in centres from 'non-affluent' countries. ${ }^{5}$

A non-atopic phenotype is the most common presentation of childhood asthma in Latin American populations. ${ }^{5-7}$ ISAAC phase II study centres in Latin America reported that only 11\% of asthma was attributable to atopy. ${ }^{5}$ These data suggest that a minority of asthma cases in Latin America may be associated with allergic sensitisation. ${ }^{4}$

Epidemiological studies in Europe have shown distinct patterns of risk factors for atopic and nonatopic asthma in children and adolescents ${ }^{8-11}$ : atopic asthma was positively associated with other allergic symptoms ${ }^{8}$ and asthma in siblings, ${ }^{8}$ but was inversely associated with household pets ${ }^{9}$; non-atopic asthma was positively associated with recurrent chest infections at 2 years, ${ }^{8}$ other earlylife infections such as otitis media and croup, ${ }^{10}$ household damp ${ }^{9}$ or mould, ${ }^{11}$ maternal smoking, ${ }^{9} 11$ breast feeding for $<3$ months ${ }^{9}$ and pet exposures during the first year of life. ${ }^{10}$ Both atopic and nonatopic asthma were associated with a family history of asthma, ${ }^{8-11}$ male sex ${ }^{8} 911$ and a higher body mass index. ${ }^{10}$ A recent study of children from a poor urban community in Southern Brazil suggested that bronchiolitis before the age of 2 years and Ascaris lumbricoides infection were risk factors for non-atopic asthma. ${ }^{7}$

Different patterns of risk factors for atopic and non-atopic asthma may indicate distinct phenotypes with different underlying causal mechanisms. The identification of such factors may provide novel information on potential causal mechanisms and future public health strategies that could be appropriately targeted for asthma prevention. The aim of the present study was to investigate risk factors for atopic and non-atopic asthma in school-age children living in a rural area of tropical Ecuador.

\section{METHODS}

\section{Study area and population}

The study was conducted among schoolchildren attending rural schools in Afro-Ecuadorian communities in the Districts of Eloy Alfaro and San Lorenzo, in Esmeraldas province in northeastern Ecuador. The characteristics of the study area and population have been described in detail elsewhere. ${ }^{12}$

\section{Study design}

A cross-sectional study was conducted among children aged 6-16 years to estimate the frequency of atopy and allergic diseases and identify 
associated risk factors in rural populations. A convenience sample of 58 communities within the two study districts was selected. Annually updated censuses were used to identify children of school age in each community. The study was conducted in small communities ( $<250$ pupils in community schools) with similar economic activities (ie, agriculture, hunting and logging). The mean community cluster size was 68.3 (range 15-230) children.

\section{Data collection \\ Questionnaire}

Data collection was performed between March 2005 and May 2007. The questionnaire was modified from the ISAAC phase II questionnaire translated into Spanish and has been extensively field tested. The questionnaire collected information about allergic diseases and risk factors as described elsewhere. ${ }^{12}$ The questionnaire was administered to the parent or guardian in the presence of the child.

\section{Allergen skin prick testing}

Allergic sensitisation was measured by skin prick testing with seven allergen extracts (Greer Laboratories, Lenoir, North Carolina, USA): Dermatophagoides pteronyssinus/farinae mix, American cockroach (Periplaneta americana), Alternaria tenuis, cat, dog, '9 southern grass mix' and 'New stock fungi mix', positive histamine and negative saline controls. A positive reaction was defined as a mean wheal diameter at least $3 \mathrm{~mm}$ greater than the saline control $15 \mathrm{~min}$ after pricking the allergen onto the the volar side of the forearm using ALK lancets (ALK, Hungerford, UK).

\section{Stool examinations}

Single stool samples were collected and analysed for geohelminth eggs and larvae using the modified Kato Katz (quantification of A lumbricoides and Trichuris trichiura) and formol-ether concentration (detection of all geohelminths including hookworm and Strongyloides stercoralis) methods. ${ }^{13}$ Infection intensities were expressed as eggs per gram (epg) of faeces.

\section{Statistical analysis}

Atopy was defined by the presence of at least one positive allergen skin test. The presence of recent wheeze was defined by reported wheezing during the previous 12 months. Recent wheeze was classified as atopic and non-atopic by the results of allergen skin tests.

Random effect logistic regression models were used to identify risk factors for recent wheeze and atopy allowing for two-level data structure (ie, individual and community levels). Variables with $p<0.20$ in univariate analyses were included in multivariate models. ORs and 95\% CIs were calculated for each variable. Polytomous logistic regression that allows a single comparison group for more than one mutually exclusive outcome was used to predict independent risk factors for atopic and non-atopic asthma. Associations between risk factors and non-atopic or atopic asthma were compared with all children without asthma or atopy. We used a two-step approach in which the unadjusted association with the two outcomes for each variable was assessed. Variables associated with at least one of two outcomes with $p<0.20$ were retained in the models. Estimates of effect were calculated using ORs and 95\% CIs with adjustment for clustering. Population-attributable fractions (PAFs) were calculated by: $\mathrm{PAF}=\mathrm{P}_{\mathrm{ew}} \times(\mathrm{OR}-1) / \mathrm{OR}$ where $\mathrm{P}_{\mathrm{ew}}$ is the prevalence of allergen skin test reactivity among children with recent wheeze. All statistical analyses were done using STATA, version 10.

\section{Ethics}

The study protocol was approved by the ethics committee of the Hospital Pedro Vicente Maldonado, Ecuador. Written informed consent was obtained from the parent of each child and signed minor assent from the child. The parent or guardian of each

Table 1 Characteristics of the study population of school-age children

\begin{tabular}{|c|c|c|}
\hline Variables & $\mathbf{n}$ & $\%$ \\
\hline \multicolumn{3}{|l|}{ Demographic and socioeconomic } \\
\hline \multicolumn{3}{|l|}{ Age, years } \\
\hline $6-9$ & $1531 / 3960$ & 38.7 \\
\hline $10-13$ & $1386 / 3960$ & 35.0 \\
\hline $14-16$ & $1043 / 3960$ & 26.3 \\
\hline \multicolumn{3}{|l|}{ Sex } \\
\hline Male & $1905 / 3960$ & 48.1 \\
\hline Female & $2055 / 3960$ & 51.9 \\
\hline \multicolumn{3}{|l|}{ Family income } \\
\hline >US\$150 & $732 / 3901$ & 18.8 \\
\hline$\leq \mathrm{US} \$ 150$ & $3169 / 3901$ & 81.2 \\
\hline \multicolumn{3}{|l|}{ Maternal education level } \\
\hline Complete secondary or higher & $309 / 3853$ & 8.0 \\
\hline $\begin{array}{l}\text { Complete primary or incomplete } \\
\text { secondary }\end{array}$ & $1330 / 3853$ & 34.5 \\
\hline Illiterate or incomplete primary & $2214 / 3853$ & 57.5 \\
\hline \multicolumn{3}{|l|}{ Household electric appliances } \\
\hline None & $700 / 3959$ & 17.7 \\
\hline $1-2$ & $2164 / 3959$ & 54.7 \\
\hline $3-4$ & $1095 / 3959$ & 27.6 \\
\hline \multicolumn{3}{|l|}{ Allergic symptoms } \\
\hline \multicolumn{3}{|l|}{ Asthma } \\
\hline Wheeze ever & $1249 / 3847$ & 32.5 \\
\hline Wheeze in past year & $406 / 3858$ & 10.5 \\
\hline \multicolumn{3}{|l|}{ Wheeze attacks in past year } \\
\hline $1-3$ attacks & $311 / 3871$ & 8.0 \\
\hline $4-12$ attacks & $69 / 3871$ & 1.8 \\
\hline$\geq 12$ attacks & $27 / 3871$ & 0.7 \\
\hline Woken by wheeze in past year & $316 / 3346$ & 9.4 \\
\hline Wheeze limiting speech in past year & $146 / 3857$ & 3.8 \\
\hline $\begin{array}{l}\text { Wheeze during or after exercise in past } \\
\text { year }\end{array}$ & $224 / 3860$ & 5.8 \\
\hline \multicolumn{3}{|l|}{ Rhinitis } \\
\hline Rhinitis ever & $480 / 3907$ & 12.3 \\
\hline Rhinitis in past year without colds & $346 / 3907$ & 8.9 \\
\hline Rhinitis in past year with itchy eyes & $246 / 3895$ & 6.3 \\
\hline \multicolumn{3}{|l|}{ Eczema } \\
\hline Eczema ever & $330 / 3912$ & 8.4 \\
\hline $\begin{array}{l}\text { Itchy rash affecting flexures in past } \\
\text { year }\end{array}$ & $191 / 3912$ & 4.9 \\
\hline $\begin{array}{l}\text { Woken at night by itchy rash in past } \\
\text { year }\end{array}$ & $83 / 3881$ & 2.1 \\
\hline \multicolumn{3}{|l|}{ Skin prick reaction $\geq 3 \mathrm{~mm}$} \\
\hline Any allergen & $477 / 3821$ & 12.5 \\
\hline House dust mite & $252 / 3821$ & 6.6 \\
\hline Mixed grass & $73 / 3821$ & 1.9 \\
\hline Cockroach & $167 / 3821$ & 4.4 \\
\hline Fungus & $18 / 3821$ & 0.5 \\
\hline Cat & $15 / 3821$ & 0.4 \\
\hline Dog & $67 / 3821$ & 1.8 \\
\hline Alternaria & $8 / 3692$ & 0.2 \\
\hline \multicolumn{3}{|l|}{ Geohelminth infections } \\
\hline Any helminth & $2851 / 3804$ & 74.9 \\
\hline Ascaris lumbricoides & $2013 / 3804$ & 52.9 \\
\hline Trichuris trichiura & $2178 / 3804$ & 57.3 \\
\hline Hookworm & $350 / 3804$ & 9.2 \\
\hline Strongyloides stercoralis & $16 / 3804$ & 0.4 \\
\hline
\end{tabular}


child was provided with a copy of all laboratory results, and all children with intestinal helminth infections were offered appropriate treatment.

\section{RESULTS}

A total of 3960 children participated in the study of which 3858 (97.4\%) provided complete information on wheeze symptoms and $3821(96.5 \%)$ underwent allergen skin testing. The number of children with complete data for both variables was 3726 (94.1\%). We evaluated $\sim 92 \%$ of school-age children resident in each community using updated censuses.

General characteristics of the study population are shown in table 1 . A monthly income $<$ US\$150 represents one minimum wage. The prevalence of infection with any geohelminth parasite was $74.9 \%$ and the prevalence of A lumbricoides, $T$ trichiura, hookworm and $S$ stercoralis was $52.9 \%, 57.3 \%, 9.2 \%$ and $0.4 \%$, respectively. The prevalence of skin test reactivity to any allergen was $12.5 \%$. The prevalence of wheeze in the previous 12 months was $10.5 \%$. None of the children with wheeze symptoms was taking regular asthma medications. The prevalence of rhinitis with itchy eyes within the previous 12 months and eczema (itchy flexural rash) was $6.3 \%$ and $4.9 \%$, respectively. Of 390 children with recent wheeze, $14.4 \%$ (56) had allergen skin test reactivity while $85.6 \%$ (334) did not. The PAFs for recent wheeze, allergic rhinitis and eczema associated with atopy were $2.4 \%, 0 \%$ and $5.6 \%$, respectively.

Table 2 Risk factors for allergen skin test reactivity

\begin{tabular}{|c|c|c|c|c|c|}
\hline Risk factor & Total $n=3.821$ & $\begin{array}{l}\text { Skin test reactivity } \\
\mathrm{n}=477\end{array}$ & $\begin{array}{l}\text { Univariate } \\
\text { OR (95\% CI) }\end{array}$ & $\begin{array}{l}\text { Multivariate } \\
\text { OR }(95 \% \mathrm{CI})\end{array}$ & p Value \\
\hline \multicolumn{6}{|l|}{ Sex } \\
\hline Female & 1855 & $189(10.2 \%)$ & 1.0 & & \\
\hline Male & 1966 & $288(14.6 \%)$ & $1.48(1.21$ to 1.81$)$ & & \\
\hline \multicolumn{6}{|l|}{ Age, years } \\
\hline $6-9$ & 1491 & $130(8.7 \%)$ & $1.0^{*}$ & & \\
\hline $10-12$ & 1340 & $186(13.9 \%)$ & 1.76 (1.38 to 2.24$)$ & & \\
\hline $13-16$ & 990 & $161(16.3 \%)$ & $2.06(1.60$ to 2.66$)$ & & \\
\hline \multicolumn{6}{|c|}{ Gas for cooking $(3) \dagger$} \\
\hline No & 220 & $39(17.7 \%)$ & 1.0 & 1.0 & \\
\hline Yes & 3598 & $438(12.2 \%)$ & 0.69 (0.47 to 1.02$)$ & $0.70(0.47$ to 1.04$)$ & 0.075 \\
\hline \multicolumn{6}{|c|}{ Consumption of river water } \\
\hline No & 1094 & $93(8.5 \%)$ & 1.0 & 1.0 & \\
\hline Yes & 2727 & $384(14.1 \%)$ & $1.40(1.02$ to 1.93$)$ & $1.40(1.01$ to 1.95$)$ & 0.043 \\
\hline \multicolumn{6}{|l|}{ Birth order $(1) \dagger$} \\
\hline $1 s t-3 r d$ & 2087 & $236(11.3 \%)$ & 1.0 & 1.0 & \\
\hline$\geq 4$ th & 1733 & $241(13.9 \%)$ & 1.24 (1.02 to 1.51$)$ & 1.20 (0.97 to 1.48$)$ & 0.090 \\
\hline \multicolumn{6}{|c|}{ Attending day care $(117) \dagger$} \\
\hline No & 1973 & $262(13.3 \%)$ & 1.0 & 1.0 & \\
\hline$<1$ year old & 462 & $45(9.7 \%)$ & $0.67(0.46$ to 0.97$)$ & $0.72(0.50$ to 1.05$)$ & \\
\hline$\geq 1$ year old & 1269 & $154(12.1 \%)$ & $0.80(0.64$ to 1.01$)$ & 0.85 (0.67 to 1.07$)$ & 0.164 \\
\hline \multicolumn{6}{|c|}{ Contact with animals in farms at least once a week $(5) \dagger$} \\
\hline No & 2625 & $290(11.0 \%)$ & 1.0 & 1.0 & \\
\hline Yes & 1191 & $186(15.6 \%)$ & $1.38(1.11$ to 1.72$)$ & $1.27(1.01$ to 1.59$)$ & 0.042 \\
\hline \multicolumn{6}{|c|}{ Mother smoked in pregnancy $(66) \dagger$} \\
\hline No & 3305 & $397(12.0 \%)$ & 1.0 & 1.0 & \\
\hline Yes & 450 & $74(16.4 \%)$ & 1.35 (1.02 to 1.80$)$ & 1.24 (0.92 to 1.68$)$ & 0.163 \\
\hline \multicolumn{6}{|c|}{ Any helminth infection (103)† } \\
\hline No & 932 & $160(17.2 \%)$ & 1.0 & 1.0 & \\
\hline Yes & 2786 & $309(11.1 \%)$ & $0.69(0.54$ to 0.87$)$ & $0.69(0.54$ to 0.87$)$ & 0.002 \\
\hline \multicolumn{6}{|c|}{ A lumbricoides infection (103)† } \\
\hline No & 1724 & $247(14.1 \%)$ & 1.0 & 1.0 & \\
\hline Yes & 1971 & $222(11.3 \%)$ & 0.84 (0.68 to 1.05$)$ & $0.96(0.76$ to 1.20$)$ & 0.713 \\
\hline \multicolumn{6}{|c|}{$T$ trichiura infection (103)† } \\
\hline No & 1590 & $265(16.7 \%)$ & 1.0 & 1.0 & \\
\hline Yes & 2128 & $204(9.6 \%)$ & $0.64(0.51$ to 0.80$)$ & $0.64(0.50$ to 0.81$)$ & $<0.001$ \\
\hline \multicolumn{6}{|c|}{ Intensity of $A$ lumbricoides infection, median (103) $\dagger$} \\
\hline Negative & 2135 & $307(14.4)$ & $1.0^{*}$ & 1.0 & \\
\hline$\leq 4620 \mathrm{epg}$ & 791 & $82(10.4 \%)$ & $0.78(0.59$ to 1.03$)$ & $0.82(0.61$ to 1.09$)$ & \\
\hline$>4620$ epg & 792 & $80(10.1 \%)$ & $0.68(0.51$ to 0.91$)$ & $0.81(0.60$ to 1.10$)$ & 0.237 \\
\hline \multicolumn{6}{|c|}{ Intensity of $T$ trichiura infection, median $(103) \dagger$} \\
\hline Negative & 1759 & $290(16.5 \%)$ & $1.0^{*}$ & $1.0 \dagger$ & \\
\hline$\leq 490 \mathrm{epg}$ & 1030 & $112(10.9 \%)$ & $0.70(0.54$ to 0.89$)$ & $0.68(0.52$ to 0.88$)$ & \\
\hline$>490$ epg & 929 & $67(7.2 \%)$ & $0.47(0.34$ to 0.64$)$ & $0.49(0.36$ to 0.68$)$ & $<0.001$ \\
\hline
\end{tabular}

Factors showing statistical significance in univariate analysis $(p<0.20)$ are shown. Multivariate $\mathrm{ORs}$ and $95 \% \mathrm{Cls}$ were calculated from random effect logistic regression model and adjusted for age and sex.

Models were made separately for: (1) any helminth; (2) prevalence of Ascaris and Trichuris infection; (3) intensity of Ascaris and Trichuris infection.

epg, eggs per gram.

*Test for trend, $p<0.001$.

†Numbers of missing values are given in parentheses. 
Table 3 Risk factors associated with wheeze in the last 12 months

\begin{tabular}{|c|c|c|c|c|c|}
\hline Risk factor & Total $n=3.858$ & Wheeze $n=406$ & Univariate OR $(95 \% \mathrm{CI})$ & Multivariate OR (95\% CI) & $\overline{\text { p Value }}$ \\
\hline \multicolumn{6}{|l|}{ Sex } \\
\hline Female & 1852 & $199(10.7 \%)$ & 1.0 & & \\
\hline Male & 2006 & $207(10.3 \%)$ & $0.96(0.78$ to 1.18$)$ & & \\
\hline \multicolumn{6}{|l|}{ Age (years) } \\
\hline $6-9$ & 1496 & $199(13.3 \%)$ & 1.0 & & \\
\hline $10-12$ & 1355 & $136(10.0 \%)$ & $0.73(0.58$ to 0.92$)$ & & \\
\hline Complete secondary or higher & 300 & $43(14.3 \%)$ & 1.0 & 1.0 & \\
\hline $\begin{array}{l}\text { Complete primary or incomplete } \\
\text { secondary }\end{array}$ & 1308 & $116(9.7 \%)$ & $0.63(0.43$ to 0.92$)$ & $0.66(0.43$ to 1.02$)$ & \\
\hline Illiterate or incomplete primary & 2167 & $207(10.7 \%)$ & $0.71(0.50$ to 1.02$)$ & $0.81(0.52$ to 1.24$)$ & 0.112 \\
\hline \multicolumn{6}{|l|}{ Family income $(49) \dagger$} \\
\hline$>$ US\$150 & 718 & $91(12.7 \%)$ & 1.0 & 1.0 & \\
\hline Wood & 1984 & $204(10.3 \%)$ & $0.82(0.57$ to 1.16$)$ & $0.78(0.53$ to 1.13$)$ & \\
\hline Mixed (wood/cement) & 662 & 70 (10.6\%) & $0.86(0.57$ to 1.29$)$ & $0.81(0.51$ to 1.28$)$ & \\
\hline Brick/block/cement & 558 & $70(12.5 \%)$ & 1.04 (0.69 to 1.57$)$ & $1.06(0.67$ to 1.67$)$ & 0.134 \\
\hline \multicolumn{6}{|l|}{ Gas for cooking (3) $\dagger$} \\
\hline No & 234 & $32(13.7 \%)$ & 1.0 & 1.0 & \\
\hline Yes & 3621 & $374(10.3 \%)$ & $0.70(0.47$ to 1.04$)$ & $0.73(0.45$ to 1.17$)$ & 0.171 \\
\hline \multicolumn{6}{|l|}{ Wood for cooking (4) $\dagger$} \\
\hline No & 2925 & $323(11.0 \%)$ & 1.0 & 1.0 & \\
\hline Yes & 929 & $82(8.8 \%)$ & $0.82(0.62$ to 1.08$)$ & 0.81 (0.58 to 1.12$)$ & 0.201 \\
\hline \multicolumn{6}{|l|}{ Consumption of river water } \\
\hline No & 1111 & $141(12.7 \%)$ & 1.0 & 1.0 & \\
\hline Yes & 2747 & $265(9.6 \%)$ & $0.76(0.59$ to 0.97$)$ & $0.84(0.65$ to 1.09$)$ & 0.193 \\
\hline \multicolumn{6}{|l|}{ Birth order (1)† } \\
\hline No & 2000 & $215(10.7 \%)$ & 1.0 & 1.0 & \\
\hline$<1$ year old & 467 & $38(8.1 \%)$ & $0.71(0.49$ to 1.03$)$ & $0.80(0.55$ to 1.18$)$ & \\
\hline$\geq 1$ year old & 1294 & $145(11.2 \%)$ & $1.05(0.83$ to 1.32$)$ & $1.11(0.87$ to 1.42$)$ & 0.254 \\
\hline \multicolumn{6}{|l|}{ Chicken outside house (3) $\dagger$} \\
\hline No & 524 & $46(8.8 \%)$ & 1.0 & 1.0 & \\
\hline Yes & 3331 & $359(10.8 \%)$ & $1.28(0.91$ to 1.78$)$ & $1.24(0.86$ to 1.77$)$ & 0.244 \\
\hline \multicolumn{6}{|l|}{ Cat inside house ever (6)† } \\
\hline No & 2174 & $205(9.4 \%)$ & 1.0 & 1.0 & \\
\hline Yes & 1678 & $198(11.8 \%)$ & $1.23(0.99$ to 1.53$)$ & $1.26(1.00$ to 1.59$)$ & 0.051 \\
\hline \multicolumn{6}{|l|}{ Breast feeding $(20) \dagger$} \\
\hline No & 69 & $12(17.4 \%)$ & 1.0 & 1.0 & \\
\hline Yes & 3769 & $392(10.4 \%)$ & $0.55(0.29$ to 1.03$)$ & $0.55(0.27$ to 1.14$)$ & 0.111 \\
\hline \multicolumn{6}{|l|}{ Frequency of exercise (16) $\dagger$} \\
\hline Daily & 2874 & $285(9.9 \%)$ & 1.0 & 1.0 & \\
\hline 3 times a week & 474 & $55(11.6 \%)$ & $1.18(0.87$ to 1.61$)$ & $1.18(0.84$ to 1.66$)$ & \\
\hline Once a week or less & 494 & $63(12.7 \%)$ & $1.35(1.00$ to 1.81$)$ & $1.19(0.85$ to 1.68$)$ & 0.432 \\
\hline Maternal allergic diseases $(93) \dagger$ & & & & & \\
\hline No & 2307 & $160(6.9 \%)$ & 1.0 & 1.0 & \\
\hline Yes & 1458 & $237(16.3 \%)$ & 2.59 (2.09 to 3.21$)$ & $2.90(2.30$ to 3.67$)$ & $<0.001$ \\
\hline A lumbricoides infection (148)† & & & & & \\
\hline No & 1741 & $166(9.5 \%)$ & 1.0 & 1.0 & \\
\hline Yes & 1969 & $222(11.3 \%)$ & $1.19(0.96$ to 1.49$)$ & $1.21(0.96$ to 1.54$)$ & 0.105 \\
\hline SPT for any allergen (132) $\dagger$ & & & & & \\
\hline No & 3261 & $334(10.2 \%)$ & 1.0 & 1.0 & \\
\hline
\end{tabular}


Table 3 Continued

\begin{tabular}{|c|c|c|c|c|c|}
\hline Risk factor & Total $n=\mathbf{3 . 8 5 8}$ & Wheeze $n=406$ & Univariate $\mathrm{OR}(95 \% \mathrm{Cl})$ & Multivariate OR (95\% CI) & p Value \\
\hline \multicolumn{6}{|c|}{ SPT for house dust mite (132) $\dagger$} \\
\hline No & 3480 & $357(10.3 \%)$ & 1.0 & 1.0 & \\
\hline Yes & 246 & $33(13.4 \%)$ & $1.39(0.94$ to 2.04$)$ & 1.59 (1.03 to 2.44$)$ & 0.035 \\
\hline No & 3563 & $368(10.3 \%)$ & 1.0 & 1.0 & \\
\hline Yes & 163 & $22(13.5 \%)$ & 1.39 (0.87 to 2.22$)$ & $1.16(0.67$ to 1.99$)$ & 0.590 \\
\hline
\end{tabular}

\section{Risk factors for allergen skin test reactivity}

The prevalence of allergen skin test reactivity increased with age (test for trend, $\mathrm{p}<0.001$ ) and was greater in males than females (table 2). Data for factors excluded from multivariate analyses (ie, univariate $p>0.20$ ) are provided in supplementary table 5 online. In multivariate analyses, consumption of river water (adjusted OR 1.40, 95\% CI 1.01 to 1.95) and contact with animals in farms (adjusted OR 1.27, 95\% CI 1.01 to 1.59) were independently associated with an increased risk of skin test reactivity. There was evidence for statistically significant inverse associations between allergen skin test reactivity and any geohelminth infection (adjusted OR $0.69,95 \%$ CI 0.54 to 0.87 ) and T trichiura infection (adjusted OR $0.64,95 \%$ CI 0.50 to 0.81 ). The prevalence of skin test reactivity declined with increasing intensities of infection with $T$ trichiura ( $\leq 490 \mathrm{epg}$; adjusted OR $0.68,95 \%$ CI 0.52 to 0.88 ; > 490 epg: adjusted OR $0.49,95 \%$ CI 0.36 to 0.68 ) (test for trend, $\mathrm{p}<0.001$ ).

\section{Risk factors for recent wheeze}

Risk factors for recent wheeze included in the multivariate model are shown in table 3. Excluded factors (ie, univariate $p>0.20)$ are shown in supplementary table 6 online. The prevalence of recent wheeze declined with age (test for trend, $\mathrm{p}<0.001)$. Multivariate analyses adjusting for age and sex showed that maternal history of allergic symptoms (adjusted OR $2.90,95 \%$ CI 2.30 to 3.67 ) and use of an open field for excreta disposal (adjusted OR 1.31, 95\% CI 1.02 to 1.68) were risk factors for recent wheeze, while birth order was inversely associated with recent wheeze (adjusted OR for $\geq 4$ th vs $<3$ rd, $0.70,95 \%$ CI 0.55 to 0.89 ). Although the majority of those with asthma were non-atopic, sensitisation to house dust mite was a risk factor for asthma (adjusted OR 1.59, 95\% CI 1.03 to 2.44 ).

\section{Risk factors for atopic and non-atopic asthma}

Stratification of wheeze by allergen skin test reactivity showed distinct risk factors for atopic and non-atopic wheeze (table 4). Atopic wheeze was positively associated with male gender (adjusted OR 2.73, 95\% CI 1.44 to 5.16) and inversely associated with intensity of $T$ trichiura infection (>490 epg vs $\leq 490$ epg: adjusted OR $0.24,95 \%$ CI 0.09 to 0.63 ). For non-atopic wheeze, watching TV for $>3 \mathrm{~h}$ per day (adjusted OR 1.51, 95\% CI 1.06 to 2.16 ) and maternal allergic diseases (adjusted OR $3.24,95 \%$ CI 2.42 to 4.32 ) were significant risk factors. The prevalence of nonatopic wheeze decreased with age (adjusted $O R$ for $\geq 13$ years old vs $<13$ years old, $0.39,95 \%$ CI 0.25 to 0.62 ) and was inversely associated with birth order (adjusted OR $0.71,95 \%$ CI 0.57 to 0.88$)$.

A comparison of the effects for risk factors associated with atopic and non-atopic wheeze showed significant differences for sex (males with greater risk of atopic wheeze, $p=0.004$ ), age (decline in prevalence with increasing age for non-atopic wheeze, $p=0.019$ ), presence of a cat inside the house (associated with increased risk of atopic but decreased risk of non-atopic wheeze, $\mathrm{p}=0.011$ ) and intensity of $T$ trichiura infection (associated with decreased risk of atopic wheeze and no association for non-atopic wheeze, $\mathrm{p}=0.010$ ).

\section{DISCUSSION}

Non-atopic asthma in childhood has been shown to be far more common than atopic asthma in non-affluent countries including in Latin America. ${ }^{5}$ The present cross-sectional study identified risk factors for atopic and non-atopic asthma in school-age children living in small communities in a poor rural area of tropical Latin America. Only a small proportion of children with asthma $(14.4 \%)$ in our study population had evidence of allergen skin test reactivity. The population fraction of asthma attributable to atopy was extremely low (2.4\%)-much lower than previous estimates for industrialised countries of $38 \%{ }^{4}$ to 40.7\%. ${ }^{5}$ However, such a low PAF was perhaps not unexpected - the ISAAC phase II study showed values of PAF $<10 \%$ in four of the 12 study centres from non-affluent countries. ${ }^{5}$ Because the value of PAF is influenced by the prevalence of allergen skin test reactivity among wheezers and the association between skin test reactivity and wheeze, factors reducing these parameters will reduce the PAFs. Such factors are likely to include those reducing atopy or the process of $\mathrm{T}$ helper 2 (Th2) polarisation such as those associated with microbial and infectious exposures, and, in our own population, chronic helminth infections that can induce potent immune regulation. ${ }^{2}{ }^{14}$

Previous studies in Latin America have shown a varying role for atopy in asthma. ${ }^{6715}$ Pereira et al studied 10-year-old children in a non-affluent community in Southern Brazil, and showed that the majority of wheeze and active asthma at the age of 10 years was non-atopic. ${ }^{7}$ In a deprived urban area of Peru, recent asthma or respiratory symptoms were not associated with atopy in children aged 8-10 years. ${ }^{6}$ In contrast, the study by Rona et al ${ }^{15}$ in adults showed a high prevalence of recent wheeze in Brazil (19.4\%) and Chile (27.4\%), and the attributable fraction of sensitisation on asthma was high for both countries (54\% for Brazil and 44\% for Chile). However, $50 \%$ of Brazilian adults were sensitised, as were $22 \%$ of Chileans. One possible explanation for the difference between these studies is the age of the study population-the association between asthma and atopy may increase with age. Further, atopic asthma may be more persistent and likely to continue into adulthood. ${ }^{16}$ Another factor that may be important is socioeconomic level-the populations studied in Brazil and Chile were relatively wealthy and the fraction of wheeze attributable to atopic sensitisation may increase with economic development. ${ }^{5}$ 
Table 4 Risk factors for atopic and non-atopic wheeze

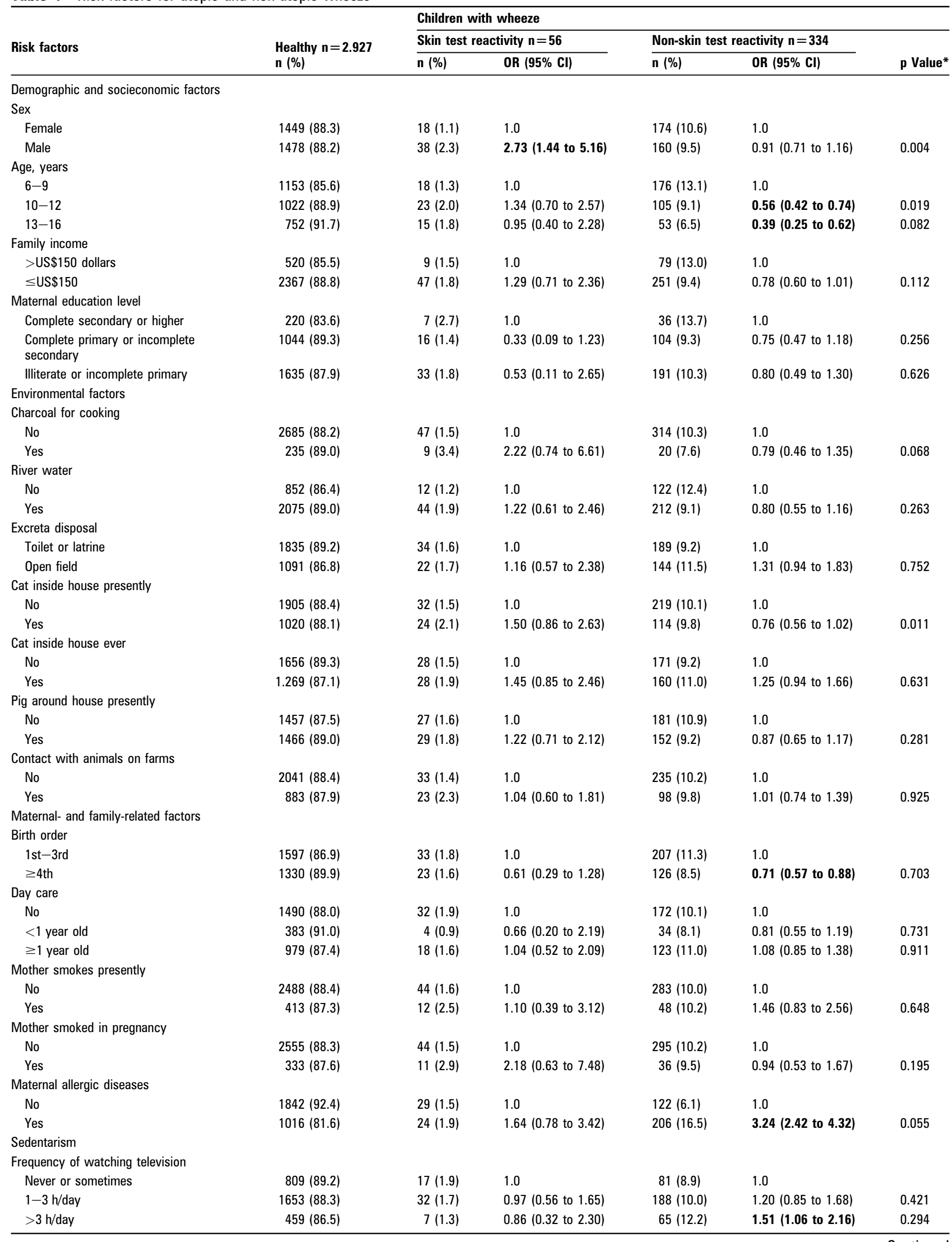


Table 4 Continued

\begin{tabular}{|c|c|c|c|c|c|c|}
\hline \multirow{3}{*}{ Risk factors } & \multirow{3}{*}{$\begin{array}{l}\text { Healthy } n=2.927 \\
n(\%)\end{array}$} & \multicolumn{5}{|c|}{ Children with wheeze } \\
\hline & & \multicolumn{2}{|c|}{ Skin test reactivity $n=56$} & \multicolumn{2}{|c|}{ Non-skin test reactivity $n=334$} & \multirow[b]{2}{*}{ p Value* } \\
\hline & & n (\%) & OR $(95 \% \mathrm{CI})$ & n (\%) & OR $(95 \% \mathrm{CI})$ & \\
\hline Daily & $2209(89.0)$ & $42(1.7)$ & 1.0 & $232(9.3)$ & 1.0 & \\
\hline 3 times a week & $349(86.8)$ & $7(1.7)$ & $0.94(0.40$ to 2.20$)$ & $46(11.5)$ & $1.23(0.82$ to 1.83$)$ & 0.562 \\
\hline Once a week or less & $363(85.8)$ & $5(1.2)$ & 0.95 (0.36 to 2.48$)$ & $55(13.0)$ & 1.32 (0.81 to 2.14$)$ & 0.471 \\
\hline Negative & $1301(88.3)$ & $36(2.5)$ & 1.0 & $136(9.2)$ & 1.0 & \\
\hline$\leq 490 \mathrm{epg}$ & 803 (88.2) & $14(1.5)$ & $0.49(0.24$ to 1.01$)$ & $93(10.3)$ & $1.00(0.74$ to 1.35$)$ & 0.072 \\
\hline$>490 \mathrm{epg}$ & $746(88.5)$ & $5(0.6)$ & $0.24(0.09$ to 0.63$)$ & $92(10.9)$ & $1.00(0.70$ to 1.43$)$ & 0.010 \\
\hline
\end{tabular}

Only the factors which had a significant effect $(p<0.20)$ in the univariate analysis for at least one of two outcomes are shown.

The $\mathrm{OR}$ and $95 \% \mathrm{Cls}$ were calculated using a polytomous logistic regression model.

epg, eggs per gram.

${ }^{*} p$ Value for the test comparing the ORs for atopic and non-atopic wheeze.

The observation of associations between different risk factors and atopic and non-atopic asthma suggests that they may be distinct asthma phenotypes. Male sex was positively associated with atopic wheeze while heavy $T$ trichiura infection was strongly inversely associated with atopic wheeze; the prevalence of non-atopic wheeze declined with age and it was positively associated with maternal allergic diseases and watching television ( $>3 \mathrm{~h} /$ day) but inversely associated with birth order. Asthma is a heterogeneous disease with different clinical phenotypes. Longitudinal studies have provided evidence for three wheeze phenotypes in childhood ${ }^{16}$ : (1) transient wheeze that is associated with impairment of lung function in early life and lower respiratory tract illnesses and may resolve by 6 years of age; (2) non-atopic wheezing occurring in the first 3 years of life that is associated with lower respiratory tract illnesses, may persist beyond 6 years and is not associated with atopy; and ( 3 ) atopic wheezing that starts before 6 years, may persist into adulthood, is strongly associated with atopy and has a more severe clinical course.

The hygiene hypothesis has tried to explain temporal trends in allergy prevalence in industrialised countries in the context of improvements in hygiene and reduced exposure to childhood infectious diseases. Our data provide some support for this hypothesis: variables related to hygiene (eg, low educational level, low income, consumption of river water, birth order, breast feeding and T trichiura infection) were negatively associated with recent wheeze, but only birth order and $T$ trichiura infections were statistically significant. Birth order was also inversely associated with symptoms of eczema and rhinitis in this population (data not shown). A systematic review of the association between allergic disease and sibling effect (birth order, number of siblings, number of older siblings and family size) showed inverse associations for sibling effect with asthma/ wheezing in 21 of 31 studies, with hay fever in 17 of 17 studies, and with eczema in nine of 11 studies. ${ }^{17}$

Asthma symptoms were inversely associated with hookworm infection but positively associated with the presence of $A$ lumbricoides infection in a meta-analysis of cross-sectional studies, ${ }^{18}$ and immunoglobulin $\mathrm{E}$ (IgE) sensitisation to $A$ lumbricoides has been identified as a risk factor for wheeze in several studies. ${ }^{19} 20$ There are very limited data on the association between intestinal helminth infections and atopic and nonatopic asthma. Pereira et $a l^{7}$ provided data to suggest that $A$ lumbricoides was an important risk factor for non-atopic asthma in a deprived community in Southern Brazil with a low prevalence of infection. Several previous studies from different geographic regions have shown inverse associations between allergen skin test reactivity and infections with the helminths $A$ lumbricoides, ${ }^{21-23}$ T trichiura ${ }^{22-24}$ and Schistosoma mansoni ${ }^{14}{ }^{25}$ In the present study $T$ trichiura infections were inversely associated with both allergen skin test reactivity and atopic asthma, with evidence of a greater effect at higher parasite burdens. The apparent protective effect of $T$ trichiura against atopic asthma may be mediated by reduced atopy. It is not clear how a purely enteric pathogen like $T$ trichiura may have effects at distant tissues sites (ie, the skin and lung). Experimental infections of mice with Heligmosomoides polygyrus, an intestinal helminth that does not migrate through the lungs, are associated with a suppression of allergen-induced airway eosinophilia ${ }^{26} 27$ and bronchial hyper-reactivity ${ }^{26}$ induced by allergen sensitisation, an effect that appears to be mediated by $\mathrm{CD} 4^{+} \mathrm{CD} 25^{+} \mathrm{T}_{\text {cells. }}{ }^{27}$

Time spent watching television is an indicator of sedentarism. A recent report provided evidence that duration of TV viewing was associated with the development of asthma in later childhood. ${ }^{28}$ Our study demonstrated that watching television for $>3 \mathrm{~h}$ per day was a risk factor only for non-atopic asthma. Some cross-sectional studies have reported a positive association between low physical activity and asthma, ${ }^{29-31}$ and this may be related to complex effects of sedentarism on respiratory physiology. ${ }^{32}$

The principal methodological limitation with our study was its cross-sectional design and the potential for information and recall bias using questionnaire data. We selected a convenience sample that was likely to be representative of Afro-Ecuadorian children of school age living in small rural communities in the study districts. Because the sample was not random we cannot exclude biases affecting generalisability of our findings to other study populations. Atopy and geohelminth prevalence and intensity were both objectively measured. Another limitation was the relatively small number of children with atopy, limiting the power to detect associations with potential risk factors. Risk factors that showed either positive $(\mathrm{OR} \geq 1.3$ ) or negative ( $O R$ $\leq 0.7$ ) associations with atopic wheeze and might have shown statistical significance with a larger sample size and more precise estimate of effect were: (1) protective factors-lower maternal educational level, fourth or more in birth order, day care during the first year of life and low infection intensity with $T$ trichiura (compared with no infection); and (2) risk factors-charcoal for cooking, household cat, maternal smoking during pregnancy and maternal history of allergic diseases.

In conclusion, the present study shows a predominance of non-atopic compared with atopic wheeze among schoolchildren 
living in a poor rural tropical region of Latin America. Further, there was evidence for different risk factors being associated with the two wheeze phenotypes that may suggest possible different causal mechanisms, and, therefore, has important implications for future preventive strategies.

Acknowledgements The Ecuadorian Elimination Programme for Onchocerciasis (Dr Eduardo Gomez, Lcda. Raquel Lovato, Lcda. Margarita Padilla, Lcda Anabel Ponce, Lcda Ing Sandra Barreno, Magdalena Cortez) and CECOMET (Dr Gregorio Montalvo and Lcda Monica Marquez) are thanked for support in visiting communities and providing community censuses. The health promoters, school teachers, parents and children are thanked for their enthusiastic cooperation. The study forms part of the SCAALA (Social Changes, Asthma, and Allergies in Latin America) programme of research.

Funding Wellcome Trust, UK, HCPC Latin American Centres of Excellence Programme (ref 072405/Z/03/Z). The funders had no role in study design, data collection and analysis, decision to publish or preparation of the manuscript.

\section{Competing interests None.}

Ethics approval This study was conducted with the approval of the ethics committee of the Hospital Pedro Vicente Maldonado, Ecuador.

Provenance and peer review Not commissioned; externally peer reviewed.

\section{REFERENCES}

1. Masoli M, Fabian D, Holt S, et al. The global burden of asthma: executive summary of the GINA dissemination committee report. Allergy 2004;59:469-78.

2. Cooper PJ, Rodrigues LC, Cruz AA, et al. Asthma in Latin America: a public heath challenge and research opportunity. Allergy 2009;64:5-17.

3. Pearce N, Ait-Khaled N, Beasley R, et al. Worldwide trends in the prevalence of asthma symptoms: phase III of the International Study of Asthma and Allergies in Childhood (ISAAC). Thorax 2007;62:758-66.

4. Pearce N, Pekkanen J, Beasley R. How much asthma is really attributable to atopy? Thorax 1999;54:268-72.

5. Weinmayr G, Weiland SK, Bjorksten B, et al. Atopic sensitization and the international variation of asthma symptom prevalence in children. Am J Respir Crit Care Med 2007;176:565-74.

6. Penny ME, Murad S, Madrid SS, et al. Respiratory symptoms, asthma, exercise test spirometry, and atopy in schoolchildren from a Lima shanty town. Thorax 2001;56:607-12.

7. Pereira MU, Sly PD, Pitrez PM, et al. Nonatopic asthma is associated with helminth infections and bronchiolitis in poor children. Eur Respir J 2007;29:1154-60.

8. Kurukulaaratchy RJ, Fenn M, Matthews S, et al. Characterisation of atopic and non-atopic wheeze in 10 year old children. Thorax 2004;59:563-8.

9. Ronmark E, Jonsson E, Platts-Mills T, et al. Different pattern of risk factors for atopic and nonatopic asthma among children-report from the obstructive lung disease in Northern Sweden Study. Allergy 1999;54:926-35.

10. Janson C, Kalm-Stephens P, Foucard T, et al. Risk factors associated with allergic and non-allergic asthma in adolescents. Clin Respir J 2007;1:16-22.

11. Garcia-Marcos L, Castro-Rodriguez JA, Suarez-Varela MM, et al. A different pattern of risk factors for atopic and non-atopic wheezing in 9-12-year-old children. Pediatr Allergy Immunol 2005;16:471-7.
12. Cooper PJ, Chico ME, Vaca MG, et al. Risk factors for asthma and allergy associated with urban migration: background and methodology of a cross-sectiona study in Afro-Ecuadorian school children in Northeastern Ecuador (EsmeraldasSCAALA Study). BMC Pulm Med 2006:6:24.

13. WHO. Diagnostic techniques for intestinal parasitic infections (IPI) applicable to primary health care (PHC) services. Geneva: WHO, 1985.

14. van den Biggelaar AH, van Ree R, Rodrigues LC, et al. Decreased atopy in children infected with schistosoma haematobium: a role for parasite-induced interleukin-10. Lancet 2000:356:1723-7.

15. Rona RJ, Vargas C, Vianna E0, et al. Impact of specific sensitization on asthma and rhinitis in young Brazilian and Chilean adults. Clin Exp Allergy 2008;38:1778-86.

16. Stein RT, Martinez FD. Asthma phenotypes in childhood: lessons from an epidemiological approach. Paediatr Respir Rev 2004;5:155-61.

17. Karmaus W, Botezan C. Does a higher number of siblings protect against the development of allergy and asthma? A review. J Epidemiol Community Health 2002; 56:209-17.

18. Leonardi-Bee J, Pritchard D, Britton J. Asthma and current intestinal parasite infection: systematic review and meta-analysis. Am J Respir Crit Care Med 2006;174:514-23.

19. Hunninghake GM, Soto-Quiros ME, Avila L, et al. Sensitization to Ascaris lumbricoides and severity of childhood asthma in Costa Rica. J Allergy Clin Immunol 2007;119:654-61.

20. Takeuchi H, Zaman K, Takahashi J, et al. High titre of anti-Ascaris immunoglobulin E associated with bronchial asthma symptoms in 5-year-old rural Bangladeshi children. Clin Exp Allergy 2008;38:276-82.

21. van den Biggelaar AH, Lopuhaa $C$, van Ree $R$, et al. The prevalence of parasite infestation and house dust mite sensitization in Gabonese schoolchildren. Int Arch Allergy Immunol 2001;126:231-8.

22. Cooper PJ, Chico ME, Bland M, et al. Allergic symptoms, atopy, and geohelminth infections in a rural area of Ecuador. Am J Respir Crit Care Med 2003;168:313-17.

23. Cooper PJ, Chico ME, Rodrigues LC, et al. Reduced risk of atopy among school-age children infected with geohelminth parasites in a rural area of the tropics. J Allergy Clin Immunol 2003;111:995-1000.

24. Rodrigues LC, Newcombe PJ, Cunha SS, et al. Early infection with Trichuris trichiura and allergen skin test reactivity in later childhood. Clin Exp Allergy 2008;38:1769-77.

25. Araujo MI, de Carvalho EM. Human schistosomiasis decreases immune responses to allergens and clinical manifestations of asthma. Chem Immunol Allergy 2006;90:29-44.

26. Kitagaki K, Businga TR, Racila D, et al. Intestinal helminths protect in a murine model of asthma. J Immunol 2006;177:1628-35.

27. Wilson MS, Taylor MD, Balic A, et al. Suppression of allergic airway inflammation by helminth-induced regulatory T cells. J Exp Med 2005;202:1199-212.

28. Sherriff A, Maitra A, Ness AR, et al. Association of duration of television viewing in early childhood with the subsequent development of asthma. Thorax 2009;64:321-5.

29. Jones SE, Merkle SL, Fulton JE, et al. Relationship between asthma, overweight, and physical activity among U.S. high school students. J Community Health 2006:31:469-78

30. Tsai HJ, Tsai AC, Nriagu J, et al. Associations of BMI, TV-watching time, and physical activity on respiratory symptoms and asthma in 5th grade schoolchildren in Taipei, Taiwan. J Asthma 2007;44:397-401

31. Firrincieli V, Keller A, Ehrensberger R, et al. Decreased physical activity among Head Start children with a history of wheezing: use of an accelerometer to measure activity. Pediatr Pulmonol 2005;40:57-63.

32. Skloot G, Permutt S, Togias A. Airway hyperresponsiveness in asthma: a problem of limited smooth muscle relaxation with inspiration. J Clin Invest 1995:96:2393-403. 